\title{
Mathematical Model of Flower Stalk Development in Chinese Cabbage Affected by Low Temperature Dropped with Gradient in Course of Time
}

\author{
Keiichiro Mori, Hiromi EgUchi and Tsuyoshi Matsui \\ Biotron Institute, Kyushu University, Fukuoka 812, Japan
}

(Received September 10, 1979)

\begin{abstract}
In previous paper, the flower stalk development promoted by low temperature dropped by step has been given as a mathematical model of the first order lag curve, where the asymptote and the delay have been used for evaluating the effect of the low temperature condition. The present paper deals with modifications and development of the mathematical model with the effect of temperature dropping gradients in course of time: The parameters of $\log _{10}\left(t_{d}+\alpha\right)$ and $\log _{10} \Delta T^{1 / 2} \cdot t_{d}^{2}$ which evaluate the low temperature effect were converted to $\log _{10}\left(t_{m}+\beta\right)$ and $\log _{10} \Delta T^{1 / 2} \cdot t_{m}^{2}$ where $\Delta T, t_{d}$ and $t_{m}$ are a degree of low temperature, treating duration with low temperature and the period settling to constant $5^{\circ} \mathrm{C}$ in temperature dropping with gradient, respectively, and $\alpha$ and $\beta$ are constancy. These parameters were useful for representation of the flower stalk development promoted by low temperature dropped by gradients. Thus, the temperature dropping gradient is able to be used as an important parameter in the present model which indicates that the low temperature effect on the flower stalk development changes with the temperature dropping gradient; the functions evaluating effect of the low temperature dropped by step are modified with a parameter $\left(t_{m}\right)$ expressing the temperature dropping gradient. From this mathematical model, it is concluded that the effect of low temperature on flower stalk development is enhanced by the temperature dropped with gradient additively and multiplicatively.
\end{abstract}

It is known that the low temperature is responsible for various morphogeneses in plants and is an important factor for plant growth and development. ${ }^{1 \sim 3)}$ However, there is difficulty in evaluating the low temperature effects, because the effect varies with many environment conditions. ${ }^{4 \sim 6)}$ In previous paper, ${ }^{7,8)}$ the mathematical model of flower stalk development in Chinese cabbage has been presented from the results of experiments under the constant controls of temperatures where the temperatures were dropped by step. While, in many cases under natural condition or practical environments for the plant cultivation, temperature changes with some gradients in course of time. So, it is necessary to evaluate the effect of temperature changing gradient. From this viewpoint, the present paper deals with presentation of a mathematical model of flower stalk development in Chinese cabbage, by using parameters of the low temperature dropped by some gradients in course of time under variable value control of temperatures. 
Plant material. Chinese cabbage, Brassica pekinensis Rupr. "Nagaoka-kohai taibyo-rokujunichi" was used. This plant is known to be sensitive to low temperature and photoperiod in flower stalk development (bolting). Plants were grown under air temperature of $20 \pm 2{ }^{\circ} \mathrm{C}$, air humidity of $75 \pm 10 \% \mathrm{RH}$ and day length of 8 hours with light intensity of about $300 \mu \mathrm{Em}^{-2} \mathrm{sec}^{-1}$ (metal halide lamp). Fifteen days old seedlings (2 leaves stage) were treated with temperatures dropping from $20^{\circ} \mathrm{C}$ to $5^{\circ} \mathrm{C}$ by different gradients, using 8 plants per experimental plot.

Treatment with low temperature. Treating temperatures were programmed by $T_{g}=20-m \cdot t_{i}$ for temperature dropping to $5^{\circ} \mathrm{C}$, where $T_{g}, m$ and $t_{i}$ are treating temperature $\left({ }^{\circ} \mathrm{C}\right)$, gradient $\left({ }^{\circ} \mathrm{C} /\right.$ day) of temperature dropping and time (day), respectively. The respective $m$ 's were set at $5,5 / 2,5 / 3$ and $5 / 4$, as shown in Fig. 1 . After temperature was dropped by respective gradients, the low temperature treatment was continued at a constant temperature of $5 \pm 1^{\circ} \mathrm{C}$ for different durations of $3,6,9,12$ and 15 days. These low temperature treatments were carried out under artificial light (20 white fluorescent lamps of $40 \mathrm{w}$ and 5 tungsten lamps of $200 \mathrm{w}$ ) with intensity of about $200 \mu \mathrm{Em}^{-2} \mathrm{sec}^{-1}$ and day length of 8 hours. After the treatments, plants were grown under the air temperature of $20 \pm 2^{\circ} \mathrm{C}$, relative humidity of $75 \pm 10 \%$ and continuous lighting (metal halide lamp) with the intensity of about 300 $\mu \mathrm{Em}^{-2} \mathrm{sec}^{-1}$.

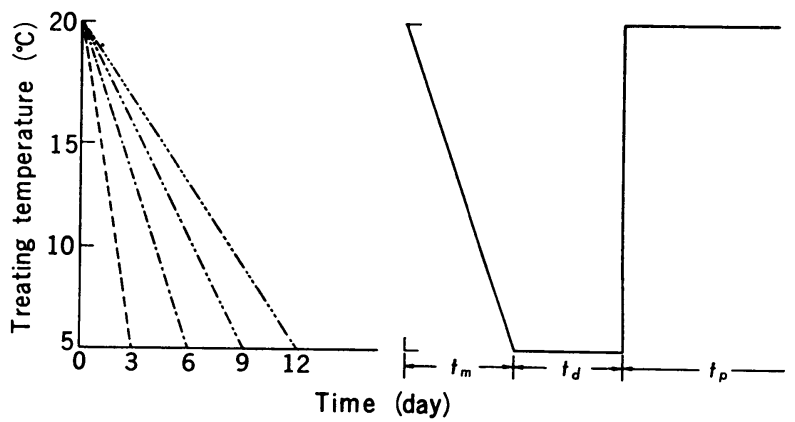

Fig. 1 Program of low temperature treatments.

$$
\begin{aligned}
& -T_{g}=5 ;-\cdots, T_{g}=20-(5 / 1) t_{i} ;---, T_{g} \\
& =20-(5 / 2) t_{i} ;-\cdots, T_{g}=20-(5 / 3) t_{i} ;----, \\
& T_{g}=20-(5 / 4) t_{i} ; t_{m}, \text { period settling to } 5^{\circ} \mathrm{C} ; t_{d}, \\
& \text { treating duration at constant } 5^{\circ} \mathrm{C} ; t_{p}, \text { time after } \\
& \text { low temperature treatment. }
\end{aligned}
$$

\section{RESULTS AND DISCUSSION}

\section{Examination of flower stalk development}

The flower stalk development was examined by measuring a distance between the cotyledonary node and the shoot apex every three days. Figure 2 shows patterns of flower stalk development in time course after the treatment. Appreciable differences among respective treatments were observed in final length of flower stalk and 


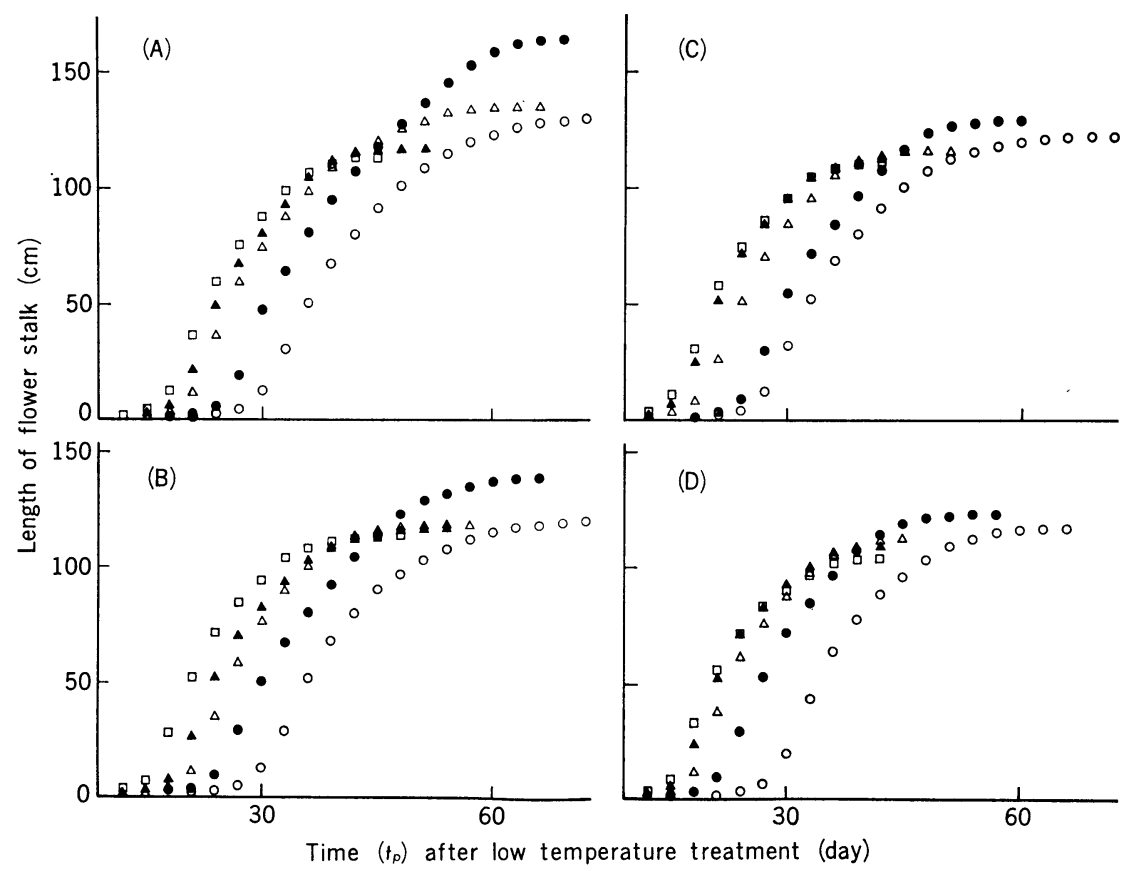

Fig. 2 Patterns of flower stalk development affected by low temperature dropping with respective gradients of $5^{\circ} \mathrm{C} / \operatorname{day}(\mathrm{A}), 5^{\circ} \mathrm{C} / 2$ days $(\mathrm{B})$, $5^{\circ} \mathrm{C} / 3$ days $(\mathrm{C})$ and $5^{\circ} \mathrm{C} / 4$ days $(\mathrm{D})$ and for treating duration of 3 days $(\bigcirc)$ at constant $5^{\circ} \mathrm{C}, 6$ days $(\bullet), 9$ days $(\triangle), 12$ days $(\bullet)$ and 15 days $(\square)$.

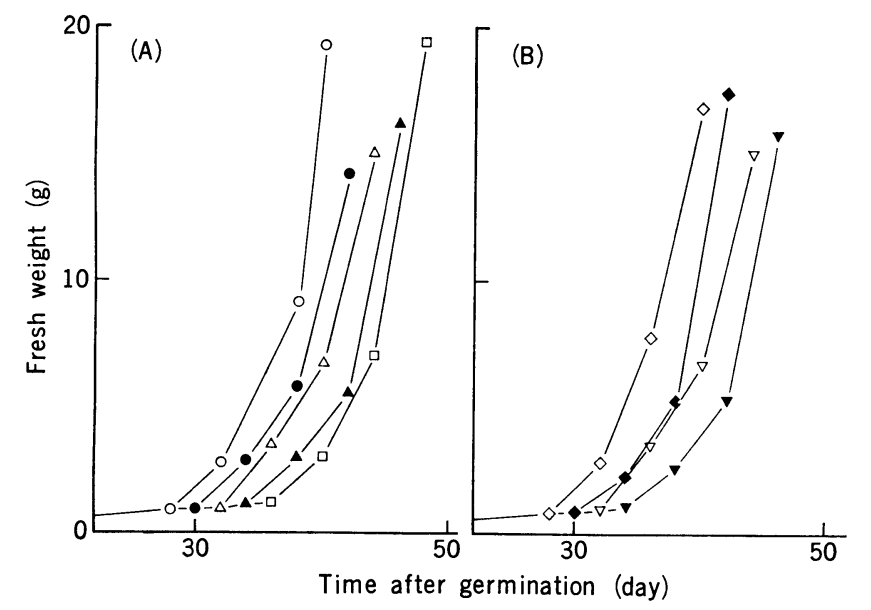

Fig. 3 Increase in fresh weight of a plant treated with respective low temperature conditions.

A; treatments with constant temperature dropping gradient of $5^{\circ} \mathrm{C} / 3$ days and with constant low temperature of $5^{\circ} \mathrm{C}$ for 3 days $(\bigcirc), 6$ days $(\bullet), 9$ days $(\triangle), 12$ days $(\boldsymbol{\Lambda})$ and 15 days $(\square)$.

$\mathrm{B}$; treatments with different temperature gradients of $5^{\circ} \mathrm{C} /$ day $(\diamond), 5^{\circ} \mathrm{C} / 2$ days $(\diamond), 5^{\circ} \mathrm{C} / 3$ days $(\nabla)$ and $5^{\circ} \mathrm{C} / 4$ days $(\nabla)$ and with constant low temperature of $5^{\circ} \mathrm{C}$ for 9 days. 
also observed in delay in rise of flower stalk development: The final length of flower stalk became smaller in the treatment with smaller temperature dropping gradients, and it was largest in low temperature treatments for 6 days with constant $5^{\circ} \mathrm{C}$ after any temperature dropping gradients. The delay in rise of flower stalk development was shortened by smaller temperature dropping gradients and also shortened by longer durations $\left(t_{d}\right.$, day) at constant $5^{\circ} \mathrm{C}$. While, these low temperature treatments inhibited the increase in fresh weight as shown in Fig. 3.

\section{Mathematical representation}

The relationship between flower stalk development and low temperature was analyzed statistically in order to evaluate the low temperature effect on the flower stalk development. The pattern of flower stalk development in time course appeared to be the sigmoid curve and was fitted to the logistic curve. For estimating this curve of higher order lag, its asymptote and delay in its rise were represented by using environmental factors, as reported in previous paper. ${ }^{7,8)}$ Figure 4 shows the asymptote of logistic curve for representing final length of flower stalk in respective treatments. The temperature dropping gradient was denoted by a period ( $t_{m}$, day) settling to $5^{\circ} \mathrm{C}$, and $t_{m}$ was used as a parameter expressing the temperature dropping gradient and also affected by the treating duration at constant $5^{\circ} \mathrm{C}$. The final lengths of flower stalk were close to a constant value in all treatments with respective dropping gradients. Similar patterns were found in relations between the final length of flower stalk and the treating duration $\left(t_{d}\right.$, day) at constant $5{ }^{\circ} \mathrm{C}$ in all treatments with respective temperature dropping gradients. The low temperature treatment in previous report $^{7,8)}$ is a case of $t_{m}=0$. So, a pattern obtained in the present paper was given by the same equation $\left(K_{s}=A_{0}+A_{1} \log _{10}\left(t_{d}+\alpha\right)+A_{2}\left\{\log _{10}\left(t_{d}+\alpha\right)\right\}^{2}\right)$ as that obtained in previous paper ${ }^{7,8)}$ as shown in Fig. 5 . In order to represent above equation of these patterns more in detail, the asymptote $\left(K_{s}, \mathrm{~cm}\right)$ was represented by using the napier's number and common logarithm of treating duration $\left(t_{d}\right.$, day) at constant $5^{\circ} \mathrm{C}$, that is,

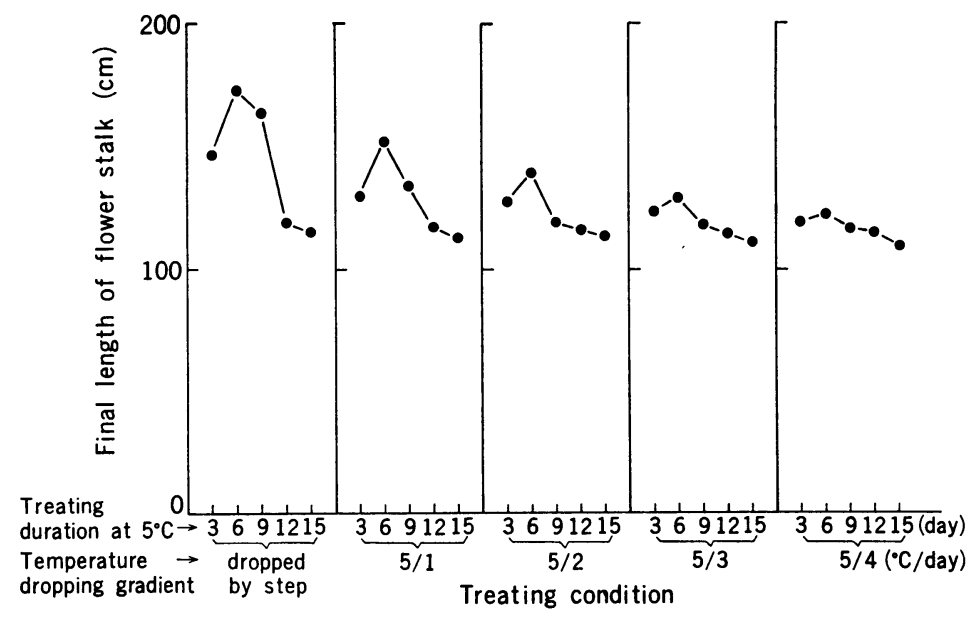

Fig. 4 Asymptote of logistic curve for representing the final length of flower stalk in respective treatments. 


$$
\begin{aligned}
K_{s}= & \gamma+\exp \left[B_{0}+B_{1} \log _{10}\left(t_{d}+\alpha\right)\right. \\
& \left.+B_{2}\left\{\log _{10}\left(t_{d}+\alpha\right)\right\}^{2}\right]
\end{aligned}
$$

where $\alpha$ is treated as 5 (days) to make $t_{d}+\alpha>0$, and $\gamma$ is given as 106.16 in this case for the reason why the final lengths of flower stalk were close to a constant value in all treatments with respective temperature dropping gradients. As mentioned before, the final length of flower stalk was affected by some temperature dropping gradients. So, $B_{0}, B_{1}$ and $B_{2}$ were represented by following functions of $t_{m}$ (day) as follows,

$$
\left.\begin{array}{rl}
B_{0}= & -47.0+28.6 \log _{10}\left(t_{m}+5\right) \\
& -2.95\left\{\log _{10}\left(t_{m}+5\right)\right\}^{2} \\
B_{1}= & 63.8-3.90 t_{m}+1.49 \\
& \times 10^{-1} t_{m}^{2} \\
B_{2}= & -31.0+1.88 t_{m} \\
& -7.22 \times 10^{-2} t_{m}^{2}
\end{array}\right\}
$$

From Eqs. (1) and (2), the asymptote $\left(K_{s}\right)$ was given by the function of $t_{d}$ and $t_{m}$ as follows,

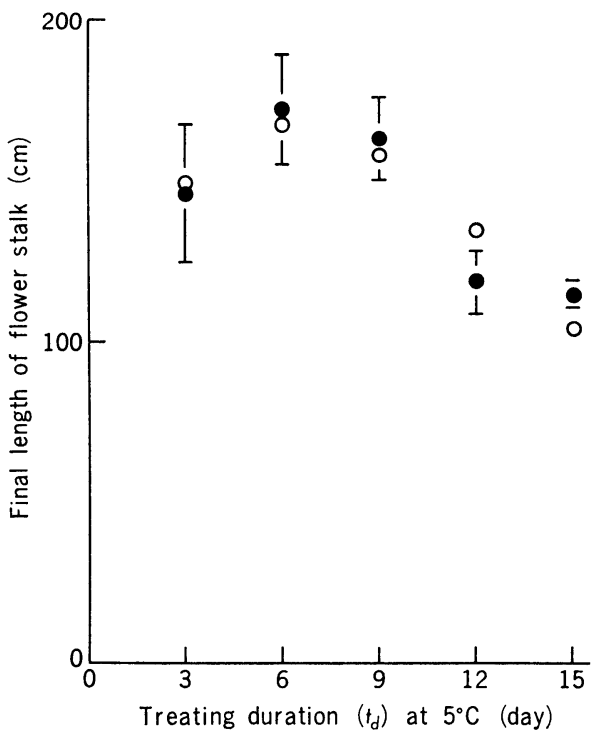

Fig. 5 Final lengths of flower stalk measured and calculated from the equation $\left(K_{s}=A_{0}+A_{1} \log _{10}\left(t_{d}+\alpha\right)+A_{2}\right.$ $\left.\left\{\log _{10}\left(t_{d}+\alpha\right)\right\}^{2}\right)$ in the treatment with the temperature dropped by step.

$(\bullet)$, measured value of final length of flower stalk; (I), its $95 \%$ confidence interval; $(O)$, calculated value given by the equation $\left(K_{s}=A_{0}+\right.$ $\left.A_{1} \log _{10}\left(t_{d}+\alpha\right)+A_{2}\left\{\log _{10}\left(t_{d}+\alpha\right)\right\}^{2}\right)$.

$$
\begin{aligned}
K_{s}= & \gamma+\exp \left[-47.0+28.6 \log _{10}\left(t_{m}+\beta\right)-2.95\left\{\log _{10}\left(t_{m}+\beta\right)\right\}^{2}\right. \\
& +\left(63.8-3.90 t_{m}+1.49 \times 10^{-1} t_{m}^{2}\right) \log _{10}\left(t_{d}+\alpha\right)+(-31.0 \\
& \left.\left.+1.88 t_{m}-7.22 \times 10^{-2} t_{m}^{2}\right)\left\{\log _{10}\left(t_{d}+\alpha\right)\right\}^{2}\right]
\end{aligned}
$$

where $15 \geqq t_{d} \geqq 3,12 \geqq t_{m} \geqq 0, \alpha=5, \beta=5, \gamma=106.16$.

Figure 6 shows final length of flower stalk, its $95 \%$ confidence interval and the asymptote $\left(K_{s}\right)$ calculated from Eq. (3) in different treatments. From the fact that most of the $K_{s}$ 's were close to the measured values of final length of flower stalk, the asymptote was represented by the function of treating duration at constant $5^{\circ} \mathrm{C}$ and temperature dropping gradient. Furthermore, the elevation $\left(B_{0}\right)$ in Eq. (1) is given by the function of $\log _{10}\left(t_{d}+\alpha\right)$ which is effective for evaluation of the effect of temperature dropping gradient, and the respective coefficients $\left(B_{1}\right.$ and $\left.B_{2}\right)$ of $\log _{10}\left(t_{d}+\alpha\right)$ evaluating the effect of constant low temperature are represented by the functions of the parameter $\left(t_{m}\right)$ expressing the temperature dropping gradient. From these facts, it is concluded that the effect of low temperature on final length 


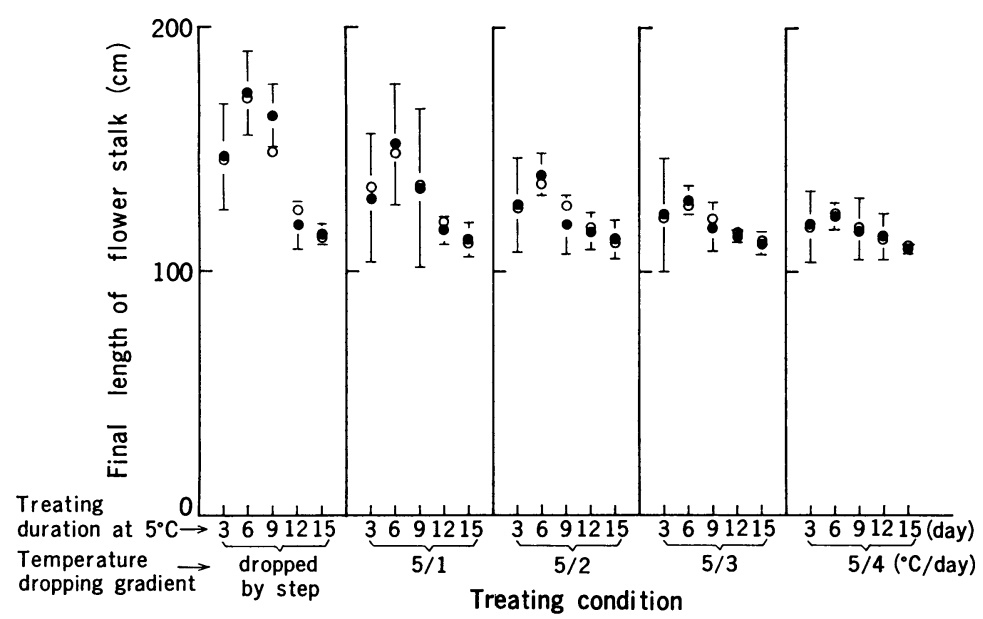

Fig. 6 Final length of flower stalk, its 95\% confidence interval and asymptote $\left(K_{s}\right)$ calculated from Eq. (3) in respective treatments.

(๑), measured value of final length of flower stalk; (I), its $95 \%$ confidence interval; (O), calculated value given by Eq. (3).

of flower stalk is enhanced by the temperature dropped with gradient additively and multiplicatively.

As mentioned before, the delay in rise of flower stalk development was characterized by the low temperature treatments. In order to evaluate the delay, the same statistical processing as that in previous pa$\operatorname{per}^{7,8)}$ was employed: The equation of logistic curve was approximated to that of the first order lag having the same value of asymptote and the same differencial coefficient at $63.2 \%(1-1 / e, e$ is napier's number $)$ of asymptote as those of the logistic curve, as shown in Fig. 7. The sum

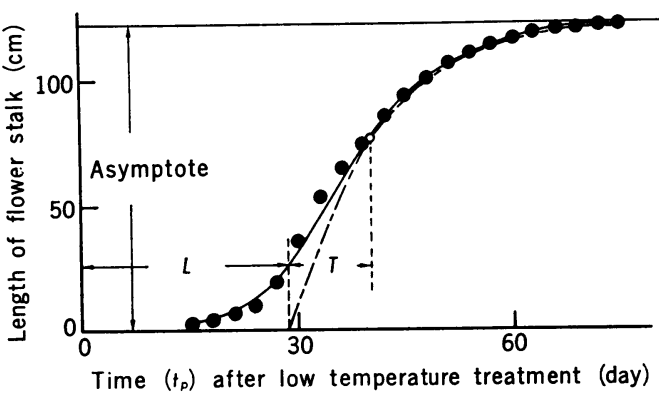

Fig. 7 Definition of evaluation of flower stalk development.

(๑), measured value of flower stalk; , logistic curve fitting to measured values; - - - curve of first order lag approximating to the logistic curve.

of the time constant and the dead time in first order lag curve was used as a parameter evaluating the time of delay, because the correlation coefficient of the time of delay on $\log _{10} \Delta T^{1 / 2} \cdot t_{d}^{2}$ is highest among the various combinations of $\Delta T$ and $t_{d}$ with significance at $0.1 \%$ level, where $\Delta T$ is a degree of the subtraction of treating temperature $\left(5^{\circ} \mathrm{C}\right)$ from untreating temperature $\left(20^{\circ} \mathrm{C}\right)$. In present experiment, high correlation coefficient $\left(\gamma=0.985\right.$ and $1 \%$ significance level) of measured time $\left(D_{d}\right.$, day) of delay on $\log _{10} \Delta T^{1 / 2} \cdot t_{d}{ }^{2}$ was obtained, when $t_{m}=0$ which is the same case as that in previous paper. ${ }^{7,8)}$ Thus, $\log _{10} \Delta T^{1 / 2} \cdot t_{d^{2}}$ was estimated to be useful as a parameter evaluating the low temperature effect, when temperature was dropped by step. The regression equation of $D_{a}$ was given by 


$$
\begin{aligned}
D_{d}= & 82.3-18.4 \\
& \times \log _{10} \Delta T^{1 / 2} \cdot t_{d}{ }^{2}
\end{aligned}
$$

When temperature was dropped by gradient, $\Delta T^{1 / 2} \cdot t_{d}^{2}$ is not enough to be used as a parameter which evaluates the effect of the temperature dropped by the gradient on the delay as shown in Fig. 8. So, it was attempted that $P_{l}$ was used as a parameter evaluating the effect of temperature dropping with gradient on the delay where the parameter $\left(P_{l}\right)$ was the function of $\Delta T^{1 / 2} \cdot t_{d}{ }^{2}$. For this reason, when $\Delta T^{1 / 2} \cdot t_{d}{ }^{2}$ was substituted for $P_{l}$ in Eq. (4), $\log _{10} P_{l}$ was given by

$$
\log _{10} P_{l}=\left(82.3-D_{d}\right) / 18.4
$$

The values of $P_{l}$ calculated from Eq. (5) were represented in respective treatments by the function of $\Delta T^{1 / 2} \cdot t_{d}^{2}$, that is,

$$
\begin{aligned}
P_{l}= & K_{0}+K_{1}\left(\Delta T^{1 / 2} \cdot t_{d}^{2}\right) \\
& +K_{2}\left(\Delta T^{1 / 2} \cdot t_{d}^{2}\right)^{2}
\end{aligned}
$$

Figure 9 shows relation between the coefficient $\left(K_{0}\right)$ in Eq. (6) and $\Delta T^{1 / 2} \cdot t_{m}{ }^{2}$, and Fig. 10 shows respective coefficients $\left(K_{1}\right.$ and $\left.K_{2}\right)$ in Eq. (6) and $t_{m}$. On the bases of these relations, $K_{0}$ was represented by the function of $\Delta T^{1 / 2} \cdot t_{m}^{2}$, and respective $K_{1}$ and $K_{2}$ were given by the functions of $t_{m}$, that is,

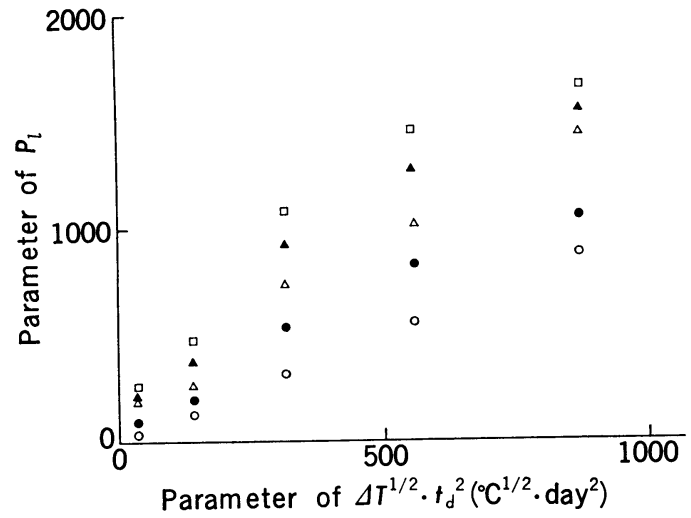

Fig. 8 Relation between the parameter $\left(P_{l}\right)$ in Eq. (5) and $\Delta T^{1 / 2} \cdot t_{d}^{2}$ in treatments with temperature dropped by step $(O)$ and with low temperature dropped by respective gradients of $5^{\circ} \mathrm{C} /$ day $(\bullet), \quad 5^{\circ} \mathrm{C} / 2$ days $(\triangle), 5^{\circ} \mathrm{C} /$ 3 days $(\mathbf{\Lambda})$ and $5^{\circ} \mathrm{C} / 4$ days $(\square)$.

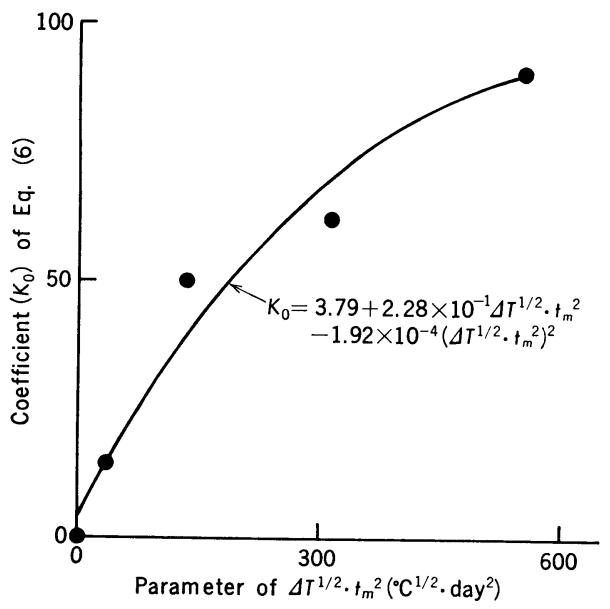

Fig. 9 Relation between the coefficient $\left(K_{0}\right)$ in Eq. (6) and $\Delta T^{1 / 2} \cdot t_{m}^{2}$.

$$
\left.\begin{array}{l}
K_{0}=3.79+2.28 \times 10^{-1} \Delta T^{1 / 2} \cdot t_{m}^{2}-1.92 \times 10^{-4}\left(\Delta T^{1 / 2} \cdot t_{m}^{2}\right)^{2} \\
K_{1}=1.06+2.25 \times 10^{-1} t_{m} \\
K_{2}=-1.79 \times 10^{-4} t_{m}
\end{array}\right\}
$$

From Eqs. (4), (6) and (7), the calculated time ( $D$, day) of the delay was represented by the function of $\Delta T, t_{d}$ and $t_{m}$, 


$$
\begin{aligned}
D= & 82.3-18.4 \log _{10}\{3.79+2.28 \\
& \times 10^{-1} \Delta T^{1 / 2} \cdot t_{m}^{2}-1.92 \\
& \times 10^{-4}\left(\Delta T^{1 / 2} \cdot t_{m}^{2}\right)^{2} \\
& +\left(1.06+2.25 \times 10^{-1} t_{m}\right) \\
& \times \Delta T^{1 / 2} \cdot t_{d}^{2}-1.79 \times 10^{-4} t_{m} \\
& \left.\times\left(\Delta T^{1 / 2} \cdot t_{d}^{2}\right)^{2}\right\}
\end{aligned}
$$

where $15 \geqq t_{d} \geqq 3,12 \geqq t_{m} \geqq 0$.

Figure 11 shows measured time of delay, its $95 \%$ confidence interval and the time $(D)$ of delay calculated from Eq. (8) in respec-

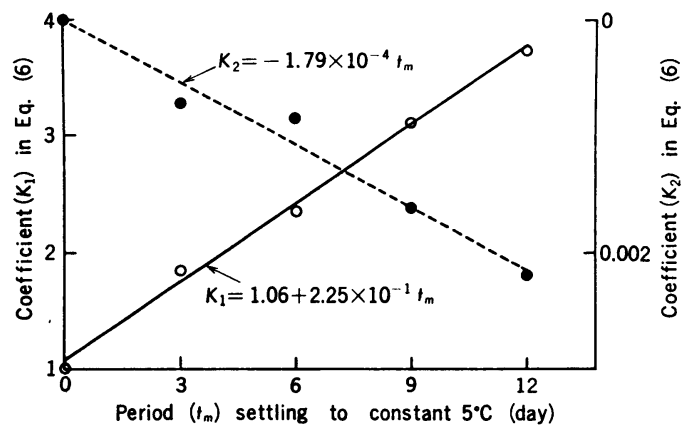

Fig. 10 Relations between the coefficients $\left(K_{1}\right.$ and $\left.K_{2}\right)$ in Eq. (6) and the period $\left(t_{m}\right)$ settling to constant $5^{\circ} \mathrm{C}$. tive treatments. From the fact that most of the $D$ 's existed within the $95 \%$ confidence intervals, it was estimated that the time of delay in rise of flower stalk development was represented by the function of treating temperature, treating duration at constant $5{ }^{\circ} \mathrm{C}$ and temperature dropping gradient. Furthermore, the elevation $\left(K_{0}\right)$ in Eq. $(6)$ is given by the function of $\Delta T^{1 / 2} \cdot t_{m}^{2}$ which is effective for evaluation of the effect of temperature dropping gradient, and the respective coefficients $\left(K_{1}\right.$ and $\left.K_{2}\right)$ of $\Delta T^{1 / 2} \cdot t_{d}^{2}$ evaluating the effect of constant low temperature are represented by the functions of the parameter $\left(t_{m}\right)$. Thus, the effect of the low temperature on the time $(D)$ of delay is enhanced by the temperature dropped with gradient additively and multiplicatively as well as that of final length of flower stalk. When the temperature is dropped by step $\left(t_{m}=0\right)$, $K_{1}$ became nearly 1 and $K_{2}$ became 0 in Eq. (6). From these facts, Eq. (8) can be also used for representation of the delay affected by low temperature dropped by step.

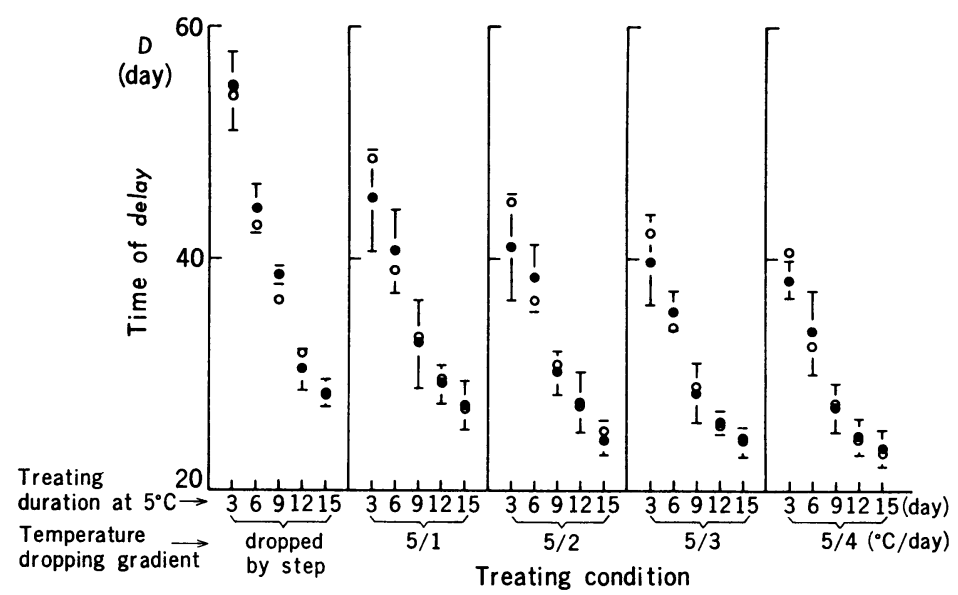

Fig. 11 Distribution of delay of flower stalk development in respective treatments.

$(\bullet)$, measured time of delay; (I), its 95\% confidence interval; $(\bigcirc)$, calculated time $(D)$ of delay given by Eq. (8). 


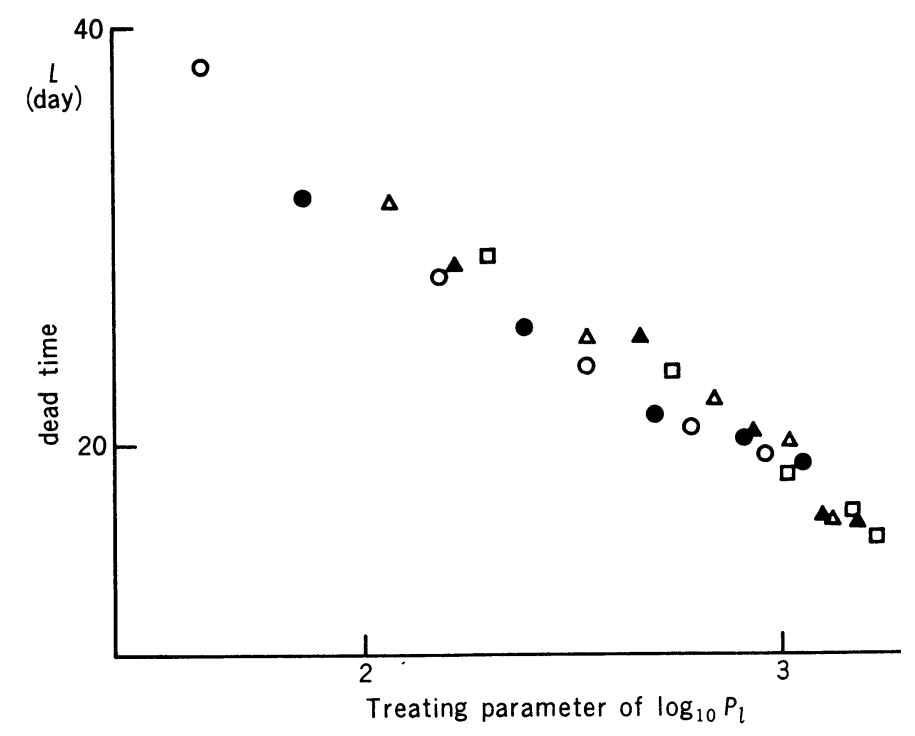

Fig. 12 Relations between the dead time $(L)$ and $\log _{10} P_{l}$ in treatments with low temperature dropped by step (O) and with low temperature dropped by respective gradients of $5^{\circ} \mathrm{C} /$ day $(\bullet), 5^{\circ} \mathrm{C} /$ 2 days $(\triangle), 5^{\circ} \mathrm{C} / 3$ days $(\Delta)$ and $5^{\circ} \mathrm{C} / 4$ days $(\square)$.

Figure 12 shows relation between dead time and $\log _{10} P_{l}$ in respective treatments. The dead time ( $L$, day) was represented by the function of $\log _{10} P_{l}$, that is,

$$
L=52.7-7.36 \log _{10} P_{l}-1.30\left(\log _{10} P_{l}\right)^{2}
$$

As mentioned before, the equation of logistic curve of flower stalk development was approximated to that of the first order lag curve to satisfy Eqs. (3), (8) and (9). So, this equation of the first order lag curve was enough to be used as the model of flower stalk development, that is, the length of flower stalk $\left(Y_{s}, \mathrm{~cm}\right)$ was given by

$$
Y_{s}=K_{s}\left[1-\exp \left\{g\left(t_{p}\right)\right\}\right]
$$

where $t_{p}$ is days after low temperature treatment, and $\left.g\left(t_{p}\right)=L / T-t_{p} / T{ }^{9}\right)$

From Eqs. (3), (8), (9) and (10), this model of flower stalk development was represented by

$$
\begin{aligned}
Y_{s}= & {\left[\gamma+\exp \left[B_{0}+B_{1} \log _{10}\left(t_{d}+\alpha\right)+B_{2}\left\{\log _{10}\left(t_{d}+\alpha\right)\right\}^{2}\right]\right] } \\
& \times\left[1-\exp \left[\left\{52.7-7.36 \log _{10} P_{l}-1.30\left(\log _{10} P_{l}\right)^{2}-t_{p}\right\}\right.\right. \\
& \left.\left.\mid\left\{29.6-11.0 \log _{10} P_{l}+1.30\left(\log _{10} P_{l}\right)^{2}\right\}\right]\right]
\end{aligned}
$$

where

$$
\begin{aligned}
& B_{0}=-47.0+28.6 \log _{10}\left(t_{m}+\beta\right)-2.95\left\{\log _{10}\left(t_{m}+\beta\right)\right\}^{2} \\
& B_{1}=63.8-3.90 t_{m}+1.49 \times 10^{-1} t_{m}^{2} \\
& B_{2}=-31.0+1.88 t_{m}-7.22 \times 10^{-2} t_{m}^{2}
\end{aligned}
$$




$$
\begin{aligned}
P_{l}= & 3.79+2.28 \times 10^{-1} \Delta T^{1 / 2} \cdot t_{m}^{2}-1.92 \times 10^{-4}\left(\Delta T^{1 / 2} \cdot t_{m}^{2}\right)^{2} \\
& +\left(1.06+2.25 \times 10^{-1} t_{m}\right) \Delta T^{1 / 2} \cdot t_{d}^{2}-1.79 \times 10^{-4} t_{m}\left(\Delta T^{1 / 2} \cdot t_{d}^{2}\right)^{2}
\end{aligned}
$$

$\alpha=5, \quad \beta=5, \gamma=106.16,15 \geqq t_{d} \geqq 3,12 \geqq t_{m} \geqq 0,75 \geqq t_{p}>0$.

Figure 13 shows examples of the curves calculated from Eq. (11) and measured values of flower stalk. From the fact that the culculated curves were close to the measured values, Eq. (11) was enough to be used as the model of flower stalk development.

In previous paper, ${ }^{8)}$ it has been reported that photoperiod is responsible for the flower stalk development as well as the low temperature, and day length $\left(d_{l}\right.$, $\mathrm{hr}$ ) is given as a parameter in the mathematical model. So, in general, the flower stalk development was expressed as follows

$$
\begin{aligned}
Y_{s}= & F\left[f_{1}\left(t_{m}\right)+f_{2}\left(t_{m}, d_{l}\right) \cdot f_{3}\left(t_{d}\right)\right] \\
& \times G\left[g_{1}\left(T_{l}, t_{m}\right)+g_{2}\left(t_{m}, d_{l}\right) \cdot g_{3}\left(T_{l}, t_{d}\right)+g_{4}\left(t_{p}\right)\right]
\end{aligned}
$$

where $Y_{s}, t_{m}, d_{l}, t_{d}$ and $T_{l}$ are the length of flower stalk, a period settling to $5^{\circ} \mathrm{C}$, day length, treating duration with low temperature and treating low temperature, respectively. Thus, it is clear that the flower stalk development in Chinese cabbage is represented by the function of respective parameters in low temperature treatment. The effect of low temperature dropped by gradients was evaluated by $\log _{10}\left(t_{d}+\alpha\right)$ and $\log _{10} \Delta T^{1 / 2} \cdot t_{m}^{2}$. The present model is also useful for evaluating the

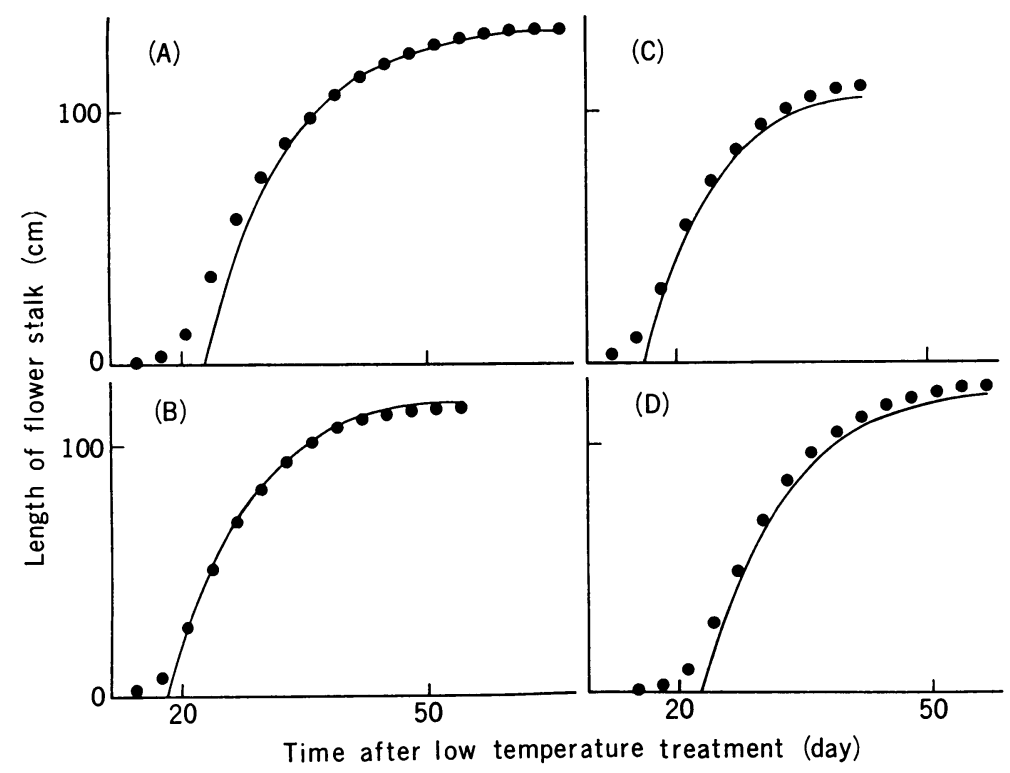

Fig. 13 Examples of the curve calculated from Eq. (11) and measured value of flower stalk in treatment with low temperature dropped by respective gradients and with constant $5^{\circ} \mathrm{C}$ for respective durations: $\mathrm{A}, m=5^{\circ} \mathrm{C} /$ day $t_{d}=9$ days; $\mathrm{B}, m=5^{\circ} \mathrm{C} / 2$ days $t_{d}=12$ days; $\mathrm{C}, m=$ $5^{\circ} \mathrm{C} / 3$ days $t_{d}=15$ days; $\mathrm{D}, m=5^{\circ} \mathrm{C} / 4$ days $t_{d}=6$ days. 
low temperature dropped by step $\left(t_{m}=0\right)$. Furthermore, present model of flower stalk development made it clear that the effect of a constant low temperature is affected by the temperature dropping gradient, that is, $\log _{10}\left(t_{d}+\alpha\right)$ and $\log _{10} \Delta T^{1 / 2} \cdot t_{d}^{2}$ are modified with the function of $t_{m}$. Thus, even when the temperature was dropped by gradients, the effect of treating duration was greater than that of treating temperature, as well as the case reported in previous paper $^{7,8)}$ where the temperature was dropped by step.

\section{REFERENCES}

1) Lorenz, O. A. 1946. Response of Chinese cabbage to temperature and photoperiod. Proc. Am. Soc. Hortic. Sci. 47: 309-319.

2) Konishi, M. 1956. Studies on development of flower stalk in long-day plants in relation to auxin metabolism. Mem. Coll. Agric. Kyoto Univ. 75: 1-70.

3) Kagawa, A. 1966. Studies on the effect of thermo-induction in floral initiation of Chinese cabbage. Res. Bull. Fac. Agric. Gifu Univ. 22: 29-39 (in Japanese).

4) Matsui, T., H. Eguchi, and K. Mori. 1977. Mathematical model of low temperature effect on female flower formation of cucumber plants in phytotron glass rooms. Environ. Control in Biol. 15: 1-9.

5) Aron, R. H. 1975. A method for estimating the number of hour below a selected temperature threshold. J. Appl. Methorol. 14: 1415-1418.

6) Yamasaki, K. 1956. Thermo-stage for the green plant of Chinese cabbage grown in spring. Bull. Hort. Div. Tokai-Kinki Agric. Exp. Sta. 1: 31-47 (in Japanese).

7) Matsui, T., H. Eguchi, and K. Mori. 1978. Mathematical model of flower stalk development in Chinese cabbage in response to low temperature. J. Fac. Agric. Kyushu Univ. 22: 233-241.

8) Mori, K., H. Eguchi, and T. Matsui. 1979. Mathematical model of flower stalk development in Chinese cabbage affected by low temperature and Photoperiod. Environ. Control in Biol. 17: 17-26.

9) Richards, F. J. 1969. The quantitative analysis of growth. In "Plant Physiology," Vol. VA (Ed. by Steward, F. C.) 3-76, Academic Press, New York and London.

〈和文抄録〉

温度勾配をもつ低温処理による白菜花茎伸長の数式モデル

森啓一郎・江口弘美・松井 健

九州大学生物環境調節センター

植物の生育および分化に関与する環境要因の作用を量的に評価するために，前報においてステップ降 下による低温ならびに日長に作用される白菜花茎伸長の数式モデルを報告した。本報告においては温度 勾配をもって降下させた低温の花荃伸長に対する効果を評価し，その評価関数を組み入れた数式モデル に発展させることを試みた，植物材料としては，春播白菜「長岡交配耐病六十日」を用い播種後 15 日 目（2葉期）の幼苗を実験に供した。温度処理は異なる温度降下勾配および $5^{\circ} \mathrm{C}$ に降下した後の異な る処理時間を設定した，その結果，花茎伸長は温度降下勾配と低温 $\left(5^{\circ} \mathrm{C}\right)$ の処理時間によって花茎の 
最終值および花茎伸長の立ち上りの遅れに明瞭な差異がみられた。 各処理条件における花茎長は低温処 理終了からの経過日数を独立変数とする logistic curve 式に適合した. この式を 1 次遅れ式に近似さ せ, 花茎の最終值および立ち上りの遅れを 1 次遅れ式の漸近值および時定数とむだ時間の和として評価 した．前報でステップ降下による低温効果の評価パラメータとして $\log _{10}\left(t_{d}+\alpha\right)\left(t_{d}\right.$ は低温処理時間, $\alpha$ は定数), $\log _{10} \Delta T^{1 / 2} \cdot t_{d^{2}}\left(\Delta T=20^{\circ} \mathrm{C}\right.$ 一処理温度）が用いられうることが明らかになったが，ある勾 配をむって降下させた低温の花茥伸長に対する効果は低温評価パラメータと同じ関数型の $\log _{10}\left(t_{m}+\beta\right)$ $\left(t_{m}\right.$ は $5^{\circ} \mathrm{C}$ になるまでの時間, $\beta$ は定数）および $\log _{10} \Delta T^{1 / 2} \cdot t_{m}{ }^{2}$ で評価された.

このモデルから，勾配をもって降下する温度も低温の効果として加算的に作用するとともに，一定低 温 $\left(5^{\circ} \mathrm{C}\right)$ の効果を相乗的な形で強めることがわかった. 